\title{
Agri-food certification schemes: how do they address greenhouse gas (GHG) emissions?
}

\author{
The number of private and voluntary agri-food standards, or certification \\ schemes, has boomed in recent years. Their proliferation and prominence has \\ been fuelled, in part, through wide-scale adoption by agri-food supply chain \\ actors using them to display environmental credentials and to signify that \\ products have been 'sustainably sourced'. As both a source of greenhouse gas \\ (GHG) emissions and a sector with significant mitigation potential, agriculture \\ has faced increasing pressures to demonstrate GHG emission reductions; it is \\ therefore important to understand whether and how GHGs are addressed within \\ certification schemes. This paper reviews a number of well-known and widely \\ applied certification schemes in the agri-food arena, focussing on several of the \\ certification schemes employed by Unilever and other multi-national companies \\ as part of their commitment to reduce their GHG footprint and source their \\ agricultural raw materials sustainably. A framework is constructed to enable \\ comparison of schemes to elucidate the differences in the range of GHG drivers \\ considered, the type of intervention in which they are addressed and how strictly \\ the GHG relevant requirements are imposed. This should be useful for companies \\ who are embarking on GHG reduction activities and are using agri-food \\ certification schemes as a mechanism to do so.
}

Keywords: agriculture, greenhouse gases (GHGs), certification scheme, management, measurement.

\section{Introduction}

The global food market is replete with private and voluntary agri-food standards or certification schemes. They are prevalent on products on supermarket shelves, feature in advertising campaigns and increasingly act as a prerequisite for business in many supply chain relations. De Battisi et al., (2009) identified over 400 private voluntary agri-food standards in use globally, designed to certify both multi-product farming systems and specific crop or livestock production systems. Whether developed 
collectively within multi-stakeholder groups (e.g. Sustainable Agriculture Network (SAN), Roundtable of Sustainable Palm Oil (RSPO)), through industry partnerships (e.g. Sustainable Agriculture Initiative - SAI - platform), or owned by individual retailers or food manufacturers (e.g. Starbucks CAFÉ practices or Tesco's NURTURE), they aim to promote and improve the sustainability of the system certified and provide a level of assurance that certain production requirements are being met. Schemes differ not only in the fashion they were developed but in their mission, scope, governance, compliance rules and respective emphasis on various socio-economic, legislative and environmental issues (Potts et al., 2010). They can operate at different levels, facilitating communication between business and consumer (B2C) or business to business (B2B) in both voluntary and regulatory contexts, and may or may not be accompanied by third-party audits or simply require self-verification. Increasingly, agrifood certification schemes are being used to differentiate products by how they were produced and sourced and to communicate this to various audiences. Now, in many ways, agri-food certification schemes have become seen as synonymous with environmental superiority, in comparison to their non-certified counterparts (e.g. Ouma, 2010).

With increasing political, media and consumer attention on climate change, greenhouse gas (GHG) emissions have come to the fore and become a proxy for broader environmental performance (UNFCCC, 2009; Trexler, 2011). The food system contributes substantially to global GHG emissions across all stages of the life cycle. Agriculture is estimated to be responsible for approximately $10-12 \%$ of anthropogenic GHG emissions globally (Smith et al., 2007) and this figure rises to $30 \%$ when associated land-use change emissions are included (EPA, 2004; Bellarby, 2008). 
Effective farm management practices can facilitate reduction or elimination of emissions, outweighing releases and possibly rendering the production system carbon neutral over its life span (Noponen et al., 2012) or even becoming a net sink. This sector therefore has a significant potential not only to reduce its own emissions but to mitigate those from other economic sectors (Robertson et al., 2000; Burney et al., 2010). Consequently, there has been increasing attention to the role of food production in GHG mitigation; several GHG reduction targets at national, regional and company level reflect this. With their role in promoting sustainable agriculture, agri-food certification schemes are widely seen as an important mechanism to help deliver these reductions, even though empirical evidence for whether they achieve this is still scant. Many manufacturers and retailers appear to be partnering with one or more schemes or developing their own. As a global example, in 2010 Unilever committed to source $100 \%$ of their agricultural raw materials sustainably and also to halve their products' environmental impact (specifically including GHGs) whilst doubling the size of the business (Unilever, 2010a). As part of this commitment Unilever works with several agri-food certification schemes, as well as developing their own, the sustainable agriculture code (SAC), to help them achieve this goal. This paper reviews Unilever's SAC (Unilever, 2010b) and nine other farm-level agri-food certification schemes used by Unilever and other multi-national companies to certify key agri-food commodities (Marks \& Spencer Group plc, 2013; Nestle, 2013; Mars, 2012). The review aims to ascertain whether and how GHG emissions are considered through the practices advocated and performance requirements stipulated. Firstly the paper introduces the certification schemes reviewed here (Section 2). It then presents a simple but comprehensive framework for reviewing and analysing the standards and scores them according to the extent to which they consider different GHG drivers (Section 3). 
Lastly, the results and key findings are presented and discussed (Section 4), whilst acknowledging the validity and limitations of the framework, the wider implications and possible further research (Section 5 and 6).

\section{Schemes reviewed}

Ten influential agri-food certification schemes that prescribe requirements for agricultural production and include environmental criteria were selected for review. These schemes were chosen because they are used by Unilever to ensure that produce purchased meets their requirements for sustainable sourcing (Unilever, 2012). They also represent a diverse and prominent range of agri-food certification schemes used by many large multinational companies globally and so have significant influence in the market place (Golden et al., 2010; www.ecolabelindex.com).

The ten schemes under review have been broadly categorised into two groups: general schemes that are designed to be applicable to several different farming systems; and specific schemes that have been designed for one particular farming system or crop type. The schemes are structured and organised differently and have different development histories. Several include standards that deal with the production of different raw materials individually or that cover specific aspects of the production chain (e.g. hired labour or primary processing). Where possible, the most general agricultural production standard document has been reviewed; otherwise one raw material standard illustrative of the scheme's overall approach to production has been assessed. Several schemes also have separate documents to provide further guidance to understand and interpret the criteria contained in the standard document (e.g. national interpretations of the RSPO standard). Where available and necessary, the additional guidance documents were consulted; however these did not feature as a key part of the 
review.

Table 1 presents some background information on the schemes that have been selected for review, with the year of establishment of the scheme, the products covered and a brief description of the scheme and its core aims. It also provides the references to the scheme documents assessed in this study.

Table 1. Overview of the agri-food certification schemes assessed in this study.

\section{Assessment Framework}

The following sub-sections describe four components of a structured, transparent and normative framework enabling a systematic relative assessment of the consideration of GHG emissions in the different schemes. The framework takes a thematic approach to characterise and categorise the qualitative information into defined groupings and rankings. Scores are assigned to provide a basis for comparison and help to unveil differences and similarities among the schemes. The four components are described in the following sections: 3.1) identification and definition of GHG drivers associated with agricultural production; 3.2) definition and classification of the types of intervention (I) to which the GHG drivers are considered in the schemes; and 3.3) three classification levels for the compliance requirement for each GHG driver at the assigned level of intervention (I). The compliance requirements provide an indication of the relative stringency (S) of the standard; each level of stringency has an associated score. Section 3.4 presents the scoring system for the assessment framework, and Section 3.5 describes the assessment process and notes some potential limitations of the framework. 


\subsection{GHG drivers}

The primary GHG emissions from agriculture are: nitrous oxides $\left(\mathrm{N}_{2} \mathrm{O}\right)$ arising from application of nitrogen based fertilisers and manure; methane $\left(\mathrm{CH}_{4}\right)$ largely from enteric fermentation of livestock, manure management, rice cultivation; and carbon dioxide $\left(\mathrm{CO}_{2}\right)$ emissions occurring through microbial decay of organic matter, combustion of plant litter and emissions from use of fossil fuels (Smith et al., 2007; Hiller et al., 2009; EPA, 2006). All emissions at farm level are dependent on complex interactions between the farmer's production practices, the geographical and geophysical state of the farm and the external environmental conditions (Van der Werf \& Petit, 2002; Milà i Canals, 2003) and thus are inherently variable. Numerous good agricultural practices (GAPs) can help to manage and reduce emissions including: changes in tillage practice to reduce soil disturbance; avoided burning and better land preparation; less agrochemical inputs and energy where possible; as well as efficient use of animal feeds, among others. Fertiliser production is responsible for approximately $1.2 \%$ of the world's GHG emissions (Kongshaug, 1998); thus improved production practices and increased efficiency can reduce the associated emissions. Furthermore, carbon can be sequestered and stored through enhancements of biomass, agroforestry, improved soil conservation and increase of soil organic matter as well as avoiding emissions from deforestation and use of fossil fuels through on-site energy generation from agricultural materials (Smith et al., 2007; Lal, 2007; Cole et al., 1997).

Through stipulation of certain management practices, promotion of specific inputs or machinery operations and requirements for evidence of implementation, agri-food certification schemes could play an important role in improving farm production practices and driving GHG improvements. The GHG drivers in this assessment have been defined and limited to include a comprehensive set of agricultural inputs, 
management practices and interactions that contribute to the raw material GHG footprint. The boundary is set at the farm-gate and only those GHG drivers that occur upstream (manufacture and transport of specified inputs to the farm: drivers a-c) and GHG drivers on-farm up to the farm-gate (primary and some secondary but subject to some control by farmer: drivers d-t) are included. Indirect GHG emissions arising from changes in product output, including effects from both within and outside the product life-cycle, are excluded as they are outside the farmer's control and are subject to greater uncertainty (Thomassen et al., 2008).

The GHG drivers included in this study (see Table 2) were identified and compiled based on an extensive literature review, including agricultural life-cycle inventories and assessments (LCAs), and farm level GHG assessments (Roches et al., 2010; Roy et al., 2009; Smith et al., 2007; Brentrup et al., 2001; Brentrup et al., 2004; Pluimers et al., 2000; Hillier et al., 2009; Fuller et al., 2003; Olander et al., 2011). Additionally, some of the most commonly used agricultural and crop-level GHG calculators were consulted, including some associated with biomass and biofuel materials, to ensure all important management sensitive GHG drivers across a number of different farming systems, crop types and geographies were considered. These included: the Cool Farm Tool (CFT) (Hillier et al., 2011); Biograce (Neeft, 2011); Carbon Accounting for Land Managers (CALM) calculator (CLA, 2009); C-Farm (Armen \& Stöckle, 2010); PalmGHG (Chase et al., 2012) and C-Plan (Dick et al., 2008) among others.

Several GHG drivers are common across agricultural production systems but can vary enormously in their relative impact on the overall GHG profile of different systems. Soils, for example, can act as both a source and a sink of GHG emissions, with different GHG release or sequestration potentials in different cultivation systems (e.g. annual vs. perennial crops). In conventional coffee production, fertiliser production can contribute 
up to $50 \%$ of the overall agricultural GHG footprint (Noponen et al., 2012). In other systems, such as palm oil, the dominant GHG contributor is deforestation and expansion onto peat land (Murdiyarso et al., 2010; Germer \& Sauerborn, 2008). This study assesses both generic and system/crop specific agri-food certification schemes. It therefore includes a comprehensive range of GHG drivers that have the potential to result in GHG reductions under some circumstances. Due to the heterogeneity of farming systems, some drivers may be relevant to some production systems but not to others. A relative scoring approach will account for these differences (see Section 3.4.1).

Due to the multiple and complex interactions that occur in an agricultural system, several GHG drivers are inextricably linked. In this sense, managing one particular GHG driver, for example land-use change, is inevitably linked to emissions arising from other drivers, i.e. soil GHG releases as well as sequestration and storage ability. The GHG drivers have been defined and distinguished to ensure that all possible sources and sinks of GHGs are included and the schemes can score for them. The review is not intended to be a footprinting exercise nor a reckoning of how a scheme could contribute to creating a GHG inventory; thus any overlaps between GHG drivers defined or 'double counting' of GHG emissions is not of substance. Three additional GHG specific criteria - GHG specific commitments, carbon neutrality and offsets, (u-w) - have been included to score schemes which include them explicitly.

The GHG drivers considered in this study:

- Can be influenced and assessed by the producer;

- Typically represent the principal influences on the GHG footprint of a crop/farm system; 
- Are those up to the farm-gate (including some upstream drivers);

- Contribute to quantifying GHG emissions through activity or other data but are not necessarily intended to provide a detailed inventory of pre farm-gate GHG sources and sinks.

Some management practices that can contribute to the raw material GHG profile were excluded from the assessment framework. These include: rotational cropping; on-farm waste-water treatment; waste reduction; transport of farm staff to and from the farm; embodied energy in food; and other indirect drivers such as indirect land-use change or other consequential GHG impacts. These are commonly omitted from LCA studies and other GHG emission reporting protocols (e.g. BSI, 2011; WRI, 2011; IPCC, 2006b) for several reasons, including complexity, uncertainty, difficulty of assessment or measurement, lack of available data or because their influence is nugatory.

Table 2 presents and describes each GHG driver included in the study and indicates which schemes are assessed for each. The number of drivers assessed is important to the total potential scores for each scheme (see 3.4). The descriptor provides some examples of the type of activities and language used within a scheme that justifies consideration of the GHG driver even when it is not included explicitly for its influence on GHG emissions.

Table 2. The GHG drivers as defined in this study and the schemes that are assessed for their inclusion.

\subsection{Types of intervention (I)}

In this study, a simple un-weighted classification system for the types of intervention (I) has been constructed to differentiate the way in which and to what extent the schemes consider each GHG driver and enable an objective comparison between schemes. 
Intervention in this study is defined as 'the type of action or method of achieving less/improved GHG emissions'. Three types of intervention have been defined to classify whether each GHG driver is managed (II), measured (I2) or if there is a performance standard (I3) in place. Any scheme may include more than one type of intervention (see Section 3.4.1). The types of intervention deal with the various approaches that may be taken to drive good practices or change on farm, from implicit action requirements (manage) to performance based requirements (performance standards). A scheme is given a score of 1 for each type of intervention included (see Section 3.4), so that there is no implication that one type is better than any other. Similarly, there is no assumption that any of the intervention types are linked, e.g. that what is measured is necessarily also managed. Table 3 presents the three classifications of intervention (I). The definitions are based on the review of literature and guidance documents related to GHG management, measurement and mitigation as well as more general management literature (Russell, 2011; Eggleston et al., 2006; WRI \& WBCSD, 2011; Herzog et al., 2006; Trexler, 2011). Alongside the definitions are some examples of the types of nomenclature used on which the classification is based.

Table 3. Intervention (I) classifications as defined in this study and examples of the nomenclature used in each.

\subsection{Stringency classification (S)}

Each scheme sets its own 'rules' for compliance per criterion in the scheme that, if met, indicate a sustainable/well-performing and therefore certifiable farm. Some schemes require full adherence to all listed or applicable criteria to receive certification, whilst others offer varying degrees of flexibility in how this is achieved. Flexibility may allow certain criteria to be met over a certain time period; may specify some criteria as 
'recommended', without any means of enforcement; or may mandate that a specified number or percentage of criteria within certain sections or chapters of the scheme be met to achieve certification. Hence it is possible that a "compliant" farm may not address some GHG drivers at all. Differences in compliance requirements make comparing the treatment of GHGs in schemes more challenging.

For a fair and meaningful comparison, a very simple differentiation between the compliance requirements is defined with three levels of stringency $(\mathrm{S})$. Here stringency is defined as 'how strictly a criterion is imposed for compliance to the scheme' and is classified on three levels; hard, medium and soft. Each GHG driver, in each of the relevant intervention types (I), is classified at a level of stringency indicating how the scheme imposes the criterion. The hard stringency classification refers to those criteria that must be met immediately to receive certification; medium stringency encompasses those criteria to be met under certain conditions; and the soft stringency classification captures optional or recommended criteria for which no evidence of fulfilment is required to achieve certification, so that they may be omitted entirely. Table 4 defines these three stringency classification levels and provides examples of nomenclature pertaining to each.

Table 4. Stringency classification definitions and example nomenclature used in various schemes.

Each GHG driver can receive a stringency classification for each type of intervention for which it is considered within a scheme. The three stringency classifications have an associated score which is outlined in the following section. 


\subsection{Scoring}

Each scheme is individually assessed and scored against the GHG drivers included, the intervention classifications (I) and the stringency classifications (S), leading to a unique total potential score (Table 2). The following section sets out the scoring rules and describes the different types of score that can be compared.

\subsubsection{Scoring rules}

One point is awarded for each relevant GHG driver (as defined in Table 2) included in the scheme at any intervention type and stringency level. The resultant total gives the comprehensiveness score.

Two types of score are then awarded per driver included. The first are the points awarded for intervention (I): for each driver, 1 point is awarded per intervention type included so that the maximum intervention points that can be awarded per driver is 3 The second score is for stringency (S): stringency scores are awarded for each GHG driver and type of intervention included. Thus each intervention - management (I1), measurement (I2) or performance standard (I3) - receives an associated stringency score: S1, S2 and S3 respectively. Whereas each intervention type is only awarded 1 point for itself, levels of stringency are assigned scores of 3, 2 and 1 points according to whether they are hard, medium or soft so that S1, S2 and S3 can each have a score from 1 - 3. The maximum stringency points that can be awarded per driver is the sum of the points awarded for each intervention, i.e. 9. The maximum score that can be achieved per GHG driver is the sum of the intervention scores $(\mathrm{I} 1+\mathrm{I} 2+\mathrm{I} 3)$ plus the sum of the stringency scores $(\mathrm{S} 1+\mathrm{S} 2+\mathrm{S} 3)=12$. Table 5 describes the different types of score that can be awarded and how these are calculated. 


\subsection{Assessment process}

The results of the assessment are presented for each scheme in Section 4. Several aspects of the assessment process bear comment:

- Type of intervention: some degree of judgement may be required to decide which type of intervention best characterises criteria within a scheme. Where any ambiguity was found, arising in less than $5 \%$ of the interventions over all the schemes considered, the classification reflects consensus among the authors acting as an expert panel.

- Double scores: it is possible that one criterion in a scheme can be scored more than once within the framework. For instance a requirement to 'manage all agrochemical applications' will score for management (I1) in both the fertilisers (d) and pesticides (e) GHG drivers. Similarly this may occur if a criterion in a scheme can be categorised as including more than one type of intervention.

- Stringency scoring: In the case that there are several criteria in the scheme that address one GHG driver with different stringency scores, the highest score takes precedence. For example, an optional criterion in scheme A might specify that 'soil pH should be measured' and thus be granted a stringency score of 1 (soft), while a subsequent mandatory criterion stipulates that records are kept including measurements of soil $\mathrm{pH}$ and so receives a stringency score of 3 (hard). In this case the higher score is recorded, i.e. 3.

- GHG driver identification: A scheme may feature the same GHG driver more than once in the context of different criteria. Biodiversity criteria for instance, 
may require tree or bush planting which is important for enhancing species diversity but also potentially increases carbon sequestration by increasing biomass and soil carbon. Schemes were assessed to recognise all GHG drivers wherever they are mentioned in the specifications of the scheme.

\section{Scheme scores}

Table 6 summarises the results from the application of the assessment framework to each of the schemes. Immediately, it is interesting to see that no schemes receive $100 \%$ in any scoring category. GlobalG.A.P receives the lowest comprehensiveness score, with just $38 \%$ of GHG drivers included in the assessment, in comparison to RA-CM which has a comprehensiveness score of $86 \%$. The scores for intervention and stringency fall in narrower ranges. The intervention scores range from $18 \%$ of the total available score for Fairtrade up to 58\% for Bonsucro. GlobalG.A.P and Fairtrade score lowest on stringency with $13 \%$ each, while RTRS and RTRS-EU combined score highest at $46 \%$.

\section{Table 6. Score summaries for all the schemes in the study.}

*Number of GHG drivers included in assessment x 12 (max. score per GHG driver)

Figure 1 shows the relation between the comprehensiveness score and the stringency score $(\mathrm{S})$ for each scheme. The area of each bubble is proportional to the overall intervention score awarded. The Figure therefore provides an initial indication of the extent to which a scheme might address all possible sources of GHG emissions relevant to the assessment. Fairtrade and GlobalG.A.P score very similarly and are clustered at the lower end of the score range. UTZ and RA score very similarly for 
comprehensiveness but RA scores slightly higher for intervention and stringency.

Several schemes score similarly and are clustered in the top right of the graph. RA, when combined with the climate module (RA-CM) moves upwards on the graph, as the comprehensiveness score increases; this is to be expected as the climate module specifies additional voluntary climate adaptation and mitigation criteria supplementary to RA. RTRS when combined with the RTRS-EU module moves right as the stringency score increases due to the RTRS-EU components being required for legal compliance. When RSPO is combined with the RSPO-EU additional compliance requirements it also moves to the right but less so than RTRS-EU. RTRS, RSPO and Bonsucro are approved for assessing contributions to renewable energy targets in the EU (Europa, 2011) and are therefore beginning to cross the border between voluntary approaches for assurance of good practices into the regulatory territory ${ }^{1}$. For biofuel products to be approved under the EU directive (2009/28/EC), these schemes must deliver ever increasing GHG benefits in comparison to conventional fossil fuels and so should score highly in this framework. LEAF and UL-SAC score very similarly for stringency but UL-SAC addresses more GHG drivers and therefore scores higher for comprehensiveness.

Figure 1. Comprehensiveness and stringency (S) scores. The size of the bubble is proportional to the overall intervention (I) score.

To move towards the upper right hand corner of Figure 1, a scheme needs to be more comprehensive and impose stricter rules for compliance. No scheme scores above $50 \%$

1 Biofuels used to achieve the EU target of 10\% renewable energy in transport by 2020 must meet minimum sustainability requirements set by member states or by voluntary schemes approved by the European Commission. See: http://ec.europa.eu/energy/renewables/biofuels/sustainability_schemes_en.htm 
for its total potential stringency score, as most do not address the full range of GHG drivers nor mandate compliance with all criteria. This would likely make a scheme too difficult to achieve and exclude a number of producers at different capacity levels. It might also be self-defeating, creating potential trade-offs by prescribing actions that may conflict, be unfeasible or not locally appropriate in certain contexts.

Figure 2 shows how the schemes score for intervention and highlights some of the trends among the schemes assessed, with the three intervention scores (I1, I2 and I3) for each scheme shown in Figure 2a. For all but one scheme (Bonsucro), the score for management intervention (I1) was the highest, with most schemes awarded over $50 \%$ of their potential I1 score; lower scores are generally recorded for measurement (I2) or performance standards (I3). Bonsucro receives the lowest I1 score of all the schemes followed by GlobalG.A.P and Fairtrade, the two generally lower scoring schemes. The score for RA and RA-CM combined stands out with the highest I1 score, receiving 90\% of its potential. A general trend amongst most schemes becomes apparent from Figure 2a: schemes typically score most highly for "manage", followed by their intervention score for "measurement", with their lowest intervention score occurring for "performance standards" where nearly all schemes scored less than $30 \%$ (or even zero) of the potential total (Fairtrade and GlobalG.A.P). Bonsucro is highlighted as an exception here: it scores very highly for both "measure" and "performance standards" (I2 and I3). This is more clearly seen in Figure $2 b$ that presents a bubble chart of the three intervention scores. Here Bonsucro is positioned very differently from the other schemes. This underlines the way Bonsucro positions itself as the first metric-based standard: it is heavily focused on measuring and setting performance targets and thresholds and requires a 'verifier' for evidence that a criterion or indicator has been met. In this way, it offers flexibility in the management approaches embarked upon, 
despite being highly prescriptive in the performance outcome required. Bonsucro is a relatively new scheme, developed in 2011 , and appears to be taking a very different approach to several of the other more established schemes that tend to set a number of 'management' requirements that should lead to good performance, rather than setting performance targets and letting the farm decide how to achieve them. This may be the most appropriate approach for the types of farm that Bonsucro is designed to certify but whether the threshold approach is successful in driving continuous GHG reductions or inspires producers to go beyond the threshold required is yet to be seen.

Second to Bonsucro for the I3 score was the UL SAC. Unilever designed this scheme for their own supply-chain, to be specific to their informational needs, and may be able to stipulate certain performance requirements as a condition of supply.

In Figure 2b, RA moves up on the graph when combined with RA-CM. It scores more highly for management requirements but there is no increase in the intervention score for performance standards: the climate module requires greater attention to management and measurement of GHG drivers but sets no performance requirements. As standards evolve and farmers become better acquainted with these practices, it is likely that this score distribution may change. This is true for all schemes: most are reviewed every 2 to 5 years, each time evolving to keep up with increasing informational requests, changing technologies, evolving legislation and new reporting requirements, as well as increased competition among schemes as they strive for further differentiation. It therefore would be useful to re-apply the assessment framework following the update of a standard to see if the score(s) change.

Figure 2. Intervention scores awarded to the schemes, I1 (manage), 12 (measure) and 13 (performance standard). 2a shows a bar graph of the three scores for each scheme. $2 \mathrm{~b}$ presents a bubble chart of the 3 intervention scores and highlights the patterns among the schemes; the area of the bubble is proportional to the 12 (measure) score. 
Figure 3 shows the extent to which selected GHG drivers are covered by each intervention type, across all the schemes, including some drivers that are important in most agricultural systems (e.g. energy, fertilisers) as well as some that are more important in specific cases such as tropical cropping systems (e.g. LUC, agroforestry). This Figure shows which GHG drivers are addressed most frequently and helps identify which GHG drivers lend themselves best to measurement and the establishment of a performance standard. For example, all the schemes require fertilisers and energy use to be measured whereas fertiliser production is included in very few. Farmers are likely to be able to measure and record the fertilisers they apply and energy they use more easily than they would be able to acquire information on the impacts of fertiliser production.

Several schemes receive scores for both managing and measuring use of crop protection chemicals (CPCs) as a GHG driver, though this was likely an unintended consequence as CPCs are more linked to other impacts such as eco-toxicity and chemical safety. The framework scores for some GHG drivers whether or not their inclusion is intended to achieve a GHG reduction; e.g. number of trees planted, which is recorded for biodiversity counts but also affects GHG emissions. This approach has been adopted to provide a complete assessment of all the GHG drivers included, in order to provide a complete picture of the practices and emission sources that schemes cover. The assessment framework does not apply a weighting to the different GHG drivers for their potential significance in a particular crop GHG footprint; therefore a scheme with a high comprehensiveness score may not have the biggest impact on the ground. For example a scheme that addresses less significant GHG drivers, such as CPCs and transport, but not fertiliser use might score higher but has potentially omitted a significant source of GHG 
emissions.

Over $60 \%$ of schemes explicitly reference GHGs or climate change and scored for this GHG criterion (u). Activities prescribed under this criterion range from raising staff awareness of climate change matters, to prescribing specific on-farm GHG mitigation activities.

Figure 3: Coverage of selected GHG drivers among all the schemes across all types of intervention.

\section{Discussion}

The schemes reviewed here are differentiated by the number and range of GHG drivers considered, the level of intervention at which each is addressed and whether schemes are management orientated or tend towards measurement and performance standards. Differences in stringency have been identified between standards and indicate the effectiveness with which GHG drivers are addressed; i.e. whether a GHG driver is mandated for certification or is an optional requirement. The results of this assessment do not show what the likely GHG performance of farms under certification will be, but is intended to aid understanding of how certification schemes track and influence GHG emissions. In reality several other factors will also influence the GHG performance of a certified farm such as the wider context in which it operates, access to information and available technology and finance, some of which may result in implementation of practices beyond those specified by the scheme. Additionally, farms are often certified by more than one scheme and so it can be difficult to attribute impact improvements to any one scheme. Adherence to a scheme is not synonymous with good GHG 
performance and more work is needed to understand this. Also important to consider is the original goal of the scheme, which may not be GHG emissions specifically; for example, the primary purpose of Fairtrade certification is to improve the livelihoods of farmers, whereas climate mitigation and GHG management is the focus of the RA-CM so that it is unsurprising that these two schemes score so differently.

As certification schemes become a more powerful force in agri-food supply chains globally (Ouma, 2010) and simultaneously the pressure on this sector to mitigate climate change increases, the need for schemes to effectively address GHG emissions and be transparent in how they do so will become greater. The results from this study are potentially useful in a number of ways. For instance, they can:

- Demonstrate which GHG drivers are addressed, and how, by the different schemes and provides a way to compare schemes for this issue;

- Highlight which schemes are mostly management oriented or are setting GHG related performance standards and additionally which schemes are beginning to collect 'measured' data to substantiate their impacts;

- Provide decision-support when selecting a scheme to use and partner with, when GHG emissions are an important consideration.

This analysis should therefore be useful for companies using certification schemes to tackle GHG emissions. For standard developers and certification bodies, this work may help inform their evolution and guide which drivers should be included to address GHG emissions and encourage potential reductions; it may also be useful in assessing how the value of a scheme might change following a review of the criteria included. Consumers with a concern for GHG emissions would benefit from increased understanding of the extent to which they can expect GHGs to have been addressed when they make a 
purchasing decision based on a certification label.

This study intended to create a framework to enable assessment and comparison and provide a basis for reviewing other schemes as required, not to produce results generalisable to the wider raft of agri-food certification schemes. It is important to acknowledge the limitations of the assessment framework which includes a measure of subjectivity based on the authors' interpretations of the schemes. The main limitation is that no weighting has been applied to the GHG drivers so that no indication of the relative importance of an individual GHG driver is provided; a scheme could therefore receive a high score without including the most significant GHG driver for a particular system or crop. Due to the range of agricultural systems covered by the schemes assessed in this study, it was not feasible to rectify this limitation but it remains an area for further research. In some cases the scores awarded may be 'optimistic' because some interpretation is required on the treatment of each criterion within a scheme; for example, a criterion may satisfy the requirements of the framework despite the wording being rather broad and ambiguous. As a specific example, RA specifies that the farmer should 'select service providers that are climate friendly'. This criterion scores for management of the three upstream GHG drivers including fertiliser and CPC production and transport of inputs to the farm (a-c) but, in reality, none may have been managed, not even the GHG footprint of the farm's energy provider. Scores awarded may therefore represent the best possible interpretation of any scheme.

\section{Conclusions and further research}

A transparent and structured framework has been provided to enable comparison of agri-food certification schemes according to the GHG drivers considered, the level of intervention and the stringency of these requirements within the schemes. However, the 
comparison which results is multi-dimensional, not a simple ranking, so that the results still require interpretation to determine which schemes can be expected to deliver best on GHG reductions. Furthermore, the outcomes of this assessment still need to be validated against real GHG performance data. Indeed, an important follow up for this study would be to validate the scheme score against actual GHG performance data for both non-certified and certified farms under similar conditions.

The differences seen between schemes in their consideration of GHGs result from a number of factors, including the agricultural systems for which the scheme is intended; whether the emissions from a particular agricultural system are of key concern compared to, for example, the primary processing; the capacity of the target user (e.g. smallholders vs. large-scale farms) and the overall goals of the different schemes. Some schemes have been developed to focus on issues other than GHG emissions, or were established before climate change became a salient concern. There is ample scope for GHG measurement and setting of performance targets within schemes as they evolve over time. If companies are using certification schemes as a mechanism to address GHG emissions, then the choice of scheme can be a significant decision. The analysis exposes the management bias of most schemes and reveals the performance-oriented approach of Bonsucro as an outlier which future schemes might well emulate, particularly as both the scientific and public debate on the quantified impacts of certification intensifies (RESOLVE, 2012; SustainAbility, 2010).

The framework is designed to enable repeatability and, so far as possible, to be independent of the user. Therefore it should be applicable to other schemes, which can be scored for comparison with those covered in this study. GHGs are just one currency 
for measurement of environmental impact; the framework could be extended to include other important impact categories such as biodiversity or water, for which good performance is not necessarily correlated with GHG emissions. This could provide some interesting results as the schemes may rank very differently for different impact categories. Other studies, particularly within the forestry sector, have developed methodologies and frameworks to compare and categorise voluntary and regulatory standards for different social and environmental criteria (McDermott et al., 2008; Holvoet \& Muys, 2004). An important next step could involve comparing and reconciling these different approaches to help inform evaluation of schemes' potential to drive improvement or in the potential development of better standards for particular impacts. Furthermore, the framework could be adjusted to suit the users' needs, including aggregation of GHG drivers or inclusion of additional drivers if required.

The ability of agri-food certification schemes to contribute to sustainable agriculture and have quantifiable impact improvements is an area of lively debate. The available evidence for their effectiveness is fragmented and largely anecdotal, focussing mainly on social metrics (Walter et al., 2003; Kamau et al., 2011); studies quantifying GHG emissions from certified farms and comparing them to non-certified farms are scarce. The approach developed here enables enhanced understanding of the content and activities prescribed within a scheme and the strictness with which they are imposed. It can therefore provide a first step towards ascertaining how different certification schemes address GHG emissions and show potential or reduced reductions through management and metrics. No current study (to our knowledge) has unveiled this in a systematic and informative way; further application and validation of the framework will strengthen the findings and begin to contribute to the debates and discussions on how agri-food certification schemes should be constructed to drive potential GHG 
benefits.

\section{References}

Armen, R. K., \& Stöckle, C. O. (2010). C-Farm: a simple model to evaluate the carbon balance of soil profiles. European Journal of Agronomy, 32, 22-29. doi: 10.1016/j.eja.2009.08.003

Bellarby J., Foereid, B., Hastings, A., \& Smith, P. (2008). Cool farming: climate impacts of agriculture and mitigation potential. Greenpeace. Retrieved from: http://marktcheck.greenpeace.at/uploads/media/Cool_Farming_Report_Final_w eb_01.pdf.

Bonsucro. (2011). BonSucro Production standard including Bonsucro EU production standard (Version 3.0 March 2011). Bonsucro. Retrieved from: http://www.bonsucro.com/assets/Bonsucro_Production_Standard_March_2011_ 3.pdf

Brentrup, F., Kusters, J., Kuhlmann, H., \& Lammel, J. (2001). Application of the life cycle assessment methodology to agricultural production: an example of sugar beet production with different forms of nitrogen fertilisers. European Journal of Agronomy, 14, 221-133. doi: 10.1016/S1161-0301(00)00098-8

Brentrup, F., Kusters, J., Kuhlmann, H., \& Lammel, J. (2004). Environmental impact assessment of agricultural production systems using the life cycle assessment methodology: I. Theoretical concept of a LCA method tailored to crop production. European Journal of Agronomy, 20, 247-264. doi: 10.1016/S11610301(03)00024-8

Burney, J. A., Davis, S. J., \& Lobell, D, B. (2010). Greenhouse gas mitigation by agricultural intensification, Proceedings of the National Academy of Sciences of the United States of America, 107, 12052-12057. doi:10.1073/pnas.0914216107

Chase L.D.C., Henson I.E., Abdul-Manan A.F.N., Agus F., Bessou C., Milà i Canals L., and Sharma M. (2012) The PalmGHG Calculator: The RSPO greenhouse gas calculator for oil palm products, Beta-version. The Roundtable for Sustainable Palm Oil - RSPO. Kuala Lumpur, Malaysia, October 2012. Retrieved from: http://www.rspo.org/en/rspo_palmghg_calculator 
Cole, C. V., Duxbury, J., Freney, J., Heinemeyer, O., Minami, K., Mosier, A., Paustian, K., Rosenburg, N., Sampson, N., Sauerbeck, D. \& Zhao, Q. (1997). Global estimates of potential mitigation of greenhouse gases by agriculture. Nutrient Cycling in Agroecosystems, 49, 221-228. doi: 10.1023/A:1009731711346

CLA. (2009). The carbon accounting for land managers (CALM) calculator. Retrieved from: www.calm.cla.org.uk

De Battisti, A. B., MacGregor, J., \& Graffham, A. (eds.) (2009). Standard bearers: Horticultural exports and private standards in Africa. London, International Institute for Environment and Development (IIED) and National Resources International (NRI): Russell Press.

Dick, J., Smith, P., Smith, R., Lilly, A., Moxey, A., Booth, J., Campbell, C., \& Coulter, D. (2008). Calculating farm scale greenhouse gas emissions. Retrieved from: http://www.cplan.org.uk/Calculating\%20GHG\%20Report.pdf

Eggleston, S., Buendia, L., Miwa, K., Ngara T., \& Tanabe, K. (eds). (2006). IPCC Guidelines for National Greenhouse Gas Inventories, Intergovernmental Panel on Climate Change. Japan: Institute for Global Environmental Strategies.

Environmental Protection Agency [EPA]. (2004). Inventory of U.S. Greenhouse Gas Emissions and Sinks: 1990-2002, EPA 430-R-04-003, U.S. Environmental Protection Agency, Washington, DC.

Environmental Protection Agency [EPA]. (2006). Global Mitigation of Non-CO2 Greenhouse Gases. (Report no. EPA 430-R-06-005), Washington, D.C: United States Environmental Protection Agency. Retrieved from: http://www.epa.gov/nonco2/econinv/downloads/GlobalMitigationFullReport.pdf

Europa. (2011). Memo: certification schemes for biofuels [Online]. Retrieved from: http://europa.eu/rapid/press-release_MEMO-11-522_en.htm?locale=en

Fairtrade International. (2011). Fairtrade standard for small producer organisations (Version 01.05.2011_v1.1). Bonn, Germany: Fairtrade Labelling Organizations International. Retrieved from: http://www.fairtrade.net/fileadmin/user_upload/content/2009/standards/docume nts/2012-07-11_SPO_EN.pdf

Fairtrade International (no date). Explanatory document for the fairtrade standard for small producer organisations. Bonn, Germany: Fairtrade Labelling Organizations International. Retrieved from: 
http://www.fairtrade.net/fileadmin/user_upload/content/2009/standards/docume nts/2012-10-01_EN_SPO_Explan_Doc_2_.pdf

Fuller, L., Chetner, S., Suave, J., Banks, T., Basarab, J., Chakraborty, S., Corbett, R., Kan, M., Neilson, D., \& Zhang, M. (2003). Development of a farm-level greenhouse gas assessment: identification of knowledge gaps and development of a science plan. Alberta Agriculture, Food and Rural Development, University of Alberta. Retrieved from:

http://www1.agric.gov.ab.ca/\$department/deptdocs.nsf/all/c19706/\$File/GHGRe port.pdf

Golden, J. S. (Ed.), Vermeer, D., Clemen, B., Michalko, A., Nguyen, D., Noyes, C., Akella, A., \& Bunting, J. (2010). An overview of ecolabels and sustainability certifications in the global marketplace. Corporate Sustainability Initiative and Nicholas Institute for Environmental Policy Solutions. Retrieved from: center.sustainability.duke,edu/sites/default/files/documents/ecolabelsreport.pdf

Germer, J., \& Sauerborn, J. (2008). Estimation of the impact of oil palm plantation establishment on greenhouse gas balance. Environment, Development and Sustainability, 10, 697-716. doi: 10.1007/s10668-006-9080-1

GlobalG.A.P. (2012). GlobalG.A.P. integrated farm assurance, all farm base, control points and compliance criteria. (Version 4.0, edition 4.0-1_Feb2012). Cologne, Germany: GlobalG.A.P. c/o FoodPlus GmbH. Retrieved from: http://www1.globalgap.org/cms/upload/The_Standard/IFA/Version_4.01_Feb2012/English/CPCC/120206_gg_ifa_cpcc_af_eng_v4_0-1.pdf

GlobalG.A.P. (2012). GlobalG.A.P. integrated farm assurance, crops base, control points and compliance criteria. (Version 4.0). Cologne, Germany: GlobalG.A.P. c/o FoodPlus GmbH . Retrieved from: http://www.globalgap.org/export/sites/default/.content/.galleries/documents/120 206_gg_ifa_cpcc_af_cb_fv_v4_0-1_en.pdf

Herzog, T., Baumert, K. A., \& Pershing, J. (2006). Target--intensity: an analysis of greenhouse gas intensity targets. World Resources Inst. Retrieved from: http://pdf.wri.org/target_intensity.pdf

Hillier, J., Hawes, C., Squire, G., Hilton, A., Wale, S., \& Smith, P. (2009). The carbon footprints of food crop production. International Journal of Agricultural Sustainability, 7, 107-118. doi: 10.3763/ijas.2009.0419 
Hillier, J., Walter, C., Malin, D., Garcia-Suarez, T., \& Mila i Canals, L. (2011). A farmfocused calculator for emission from crop and livestock production.

Environmental Modelling and Software, 26, 1070-1078. doi:

10.1016/j.envsoft.2011.03.014

Holvoet, B. \& Muys, B. (2004). Forest management worldwide: a comparative assessment of standards. International Forestry Review, 6, 99-122. doi: http://dx.doi.org/10.1505/ifor.6.2.99.38388

Kamau, M., Mose, L., Fort, L., \& Ruben, R. (2011). The impact of certification on smallholder coffee farmers in Kenya: the case of UTZ program (WPS 47/2011). Retrieved from: http://www.tegemeo.org/documents/work/WP47-The-Impactof-Certification-on-Smallholder-Coffee-Farmers-in-Kenya-The-case-of-UTZprogram.pdf

Kongshaug, G. (1998, September). Energy Consumption and Greenhouse Gas Emissions in Fertilizer Production. Presented at IFA Technical Conference, Marrakech, Morocco.

Lal, R. (2007). Carbon management in agricultural soils. Mitigation and Adaptation strategies for Global Change, 12, 303-322. doi: 10.1007/s11027-006-9036-7

Linking Farming and Environment (LEAF). (2012). LEAF marque global standard (Version 10.0, issued 01/10/2012). Warwickshire, UK: Leaf Marque Ltd. Retrieved from: http://www.leafuk.org/resources/000/678/140/LEAF_Marque_Global_Standard _ver_10.pdf

Linking Farming and Environment (LEAF). (2012). LEAF marque standard additional guidance notes 2012 (Version 1). Warwickshire, UK: Leaf Marque Ltd. Retrieved from: http://www.leafuk.org/resources/000/690/510/LEAF_Marque_Standard_Additio nal_Guidance_Notes_2012_version_1.pdf

Marks \& Spencer Group plc. (2013). Plan A report 2013. Retrieved from: http://planareport.marksandspencer.com/docs/33722_M\&S_PlanA_Pillar5.pdf Mars (2012). Our supply chain [Online]. Retrieved from: http://www.mars.com/global/about-mars/mars-pia/our-supply-chain.aspx

McDermott, C. L., Noah, E., \& Cashore, B. (2008). Differences that 'matter'? A framework for comparing environmental certification standards and government 
policies. Journal of Environmental Policy and Planning, 10, 47-70. doi:

$10.1080 / 15239080701652607$

Milà i Canals, L. (2003). Contributions to LCA methodology for agricultural systems.

Site-dependency and soil degradation impact assessment. $\mathrm{PhD}$ thesis,

Universitat Autonoma de Barcelona, Spain. Retrieved from:

http://www.tdx.cat/TDX-1222103-154811/

Murdiyarso, D., Hergoualc'h, K., \& Verchot, L. V. (2010). Opportunities for reducing greenhouse gas emissions in tropical peatlands, PNAS, 107, 19655-19660. doi: 10.1073/pnas.0911966107

Neeft, J. (2011). Biograce - complete list of standard values, Version 4 public to harmonise European GHG calculations. Retrieved from:

http://www.biograce.net/content/ghgcalculationtools/standardvalues

Nestle (2013). Responsible sourcing [Online]. Retrieved from:

http://www.nestle.com/csv/responsible-sourcing

Noponen, M. R. A., Edwards-Jones, G., Haggar, J. P., Soto, G., Attarzadeh, N., \& Healey, J. R. (2012). Greenhouse gas emission in coffee grown with differing input levels under conventional and organic management, Agriculture, Ecosystems \& Environment, 151, 6-15. doi:10.1016/j.agee.2012.01.019

Olander, L. P., Eagle, A. J., Baker, J. S., Haugen-Kozyra, K., Murray, B., Kravchenko, A., Henry, L. R. \& Jackson, R. B. (2011). Assessing Greenhouse Gas Mitigation Opportunities and Implementation Strategies for Agricultural Land Management in the United States (NI R 11-09). Retrieved from: http://nicholasinstitute.duke.edu/sites/default/files/publications/ni_r_11-09.pdf

Ouma, S. (2010). Global standards, local realities: private agrifood governance and the restructuring of the Kenyan horticulture industry, Economic Geography, 86, 197-222. doi: 10.1111/j.1944-8287.2009.01065.x

Pluimers, J. C., Kroeze, C., Bakker, E. J., Challa, H., \& Hordijk, L. (2000). Quantifying the environmental impact of production in agriculture and horticulture in The Netherlands: which emissions do we need to consider? Agricultural Systems, 66, 167-189. doi: 10.1016/S0308-521X(00)00046-9

Potts, J., van der Meet, J., \& Daitchman, J. (2010). The state of sustainability initiatives review 2010: Sustainability and transparency. Canada: International Institute for Sustainable Development (IISD) and the International Institute for Environment and Development (IIED). 
RESOLVE (2012). Toward sustainability: the roles and limitations of certification. Washington, DC: RESOLVE, Inc. Retrieved from: http://www.resolv.org/siteassessment/files/2012/06/Report-Only.pdf

Robertson, G. P., Paul, E. A. \& Harwood, R. R. (2000). Greenhouse gases in intensive agriculture: contributions of individual gases to the radiative forcing of the atmosphere, Science, 289, 1922-1925. doi: 10.1126/science.289.5486.1922

Roches, A., Nemecek, T., Gaillard, G., Plassmann, K., Sim, S., King, H., \& Milà i Canals, L. (2010). MEXALCA: a modular method for the extrapolation of crop LCA. International Journal of Life Cycle Assessment, 15, 842-854. doi: 10.1007/s11367-010-0209-y

Roundtable of Responsible Soy (RTRS). (2010). RTRS - Production standard for responsible soy (Version 1.0, June 2010). Sao Paulo, Brazil: RTRS. Retrieved from: http://www.fao.org/bioenergy/281800827ebfc9bfa4f6396d24bb420a8c206c.pdf

Roundtable of Responsible Soy (RTRS). (2011). RTRS EU RED compliance requirements for producers (Version 3.0_Eng). Sao Paulo, Brazil: RTRS. Retrieved from: http://ec.europa.eu/energy/renewables/biofuels/sustainability_schemes_en.htm Roundtable on Sustainable Palm Oil (RSPO). (2007) RSPO- principles and criteria for sustainable palm oil production. RSPO. Retrieved from: http://www.rspo.org/files/resource_centre/keydoc/2\%20en_RSPO\%20Principles $\% 20$ and $\% 20$ Criteria $\% 20$ for $\% 20$ Sustainable $\% 20$ Palm $\% 20$ Oil $\% 20$ Production $\% 2$ 0(2007).pdf

Roundtable on Sustainable Palm Oil (RSPO), (2012). Roundtable on sustainable palm oil (http://www.rspo.org/).

Roundtable on Sustainable Palm Oil (RSPO). (2012). RSPO-RED requirements for compliance with the EU Renewable Energy Directive requirements. (Version 4 10 February 2012, final version). RSPO. Retrieved from: http://ec.europa.eu/energy/renewables/biofuels/sustainability_schemes_en.htm Roy, P., Nei, D., Orikasa, T., Xu, Q., Nakamura, N., \& Shiina, T. (2009). A review of life cycle assessment (LCA) on some food products. Journal of Food Engineering, 90, 1-10. doi: 10.1007/s11367-010-0209-y

Russell, S. (2011). Corporate Greenhouse Gas Inventories for the Agricultural Sector: Proposed accounting and reporting steps.WRI Working Paper. Washington, 
DC.: World Resources Institute. Retrieved from:

http://www.wri.org/publications

Smith P., Martino, D., Cai, Z., Gwary, D., Janzen, H., Kumar, P., McCarl, B., Ogle, S., O'Mara, F., Rice, C., Scholes, B., Sirotenko, O., Howden, M., McAllister, T., Pan, G., Romanenkov, V., Schneider, U. and Towprayoon, S. (2007). Policy and technological constraints to implementation of greenhouse gas mitigation options in agriculture. Agriculture, Ecosystems and Environment 118, 6-28.

SustainAbility (2010). Rate the raters [Online]. Retrieved from: http://www.sustainability.com/projects/rate-the-raters

Sustainable Agriculture Initiative (SAI) Platform, (2010). Sustainable Agriculture Initiative (http://www.saiplatform.org/).

Sustainable Agriculture Network (SAN). (2010). Sustainable agriculture network. (www.sanstandards.org/sitio/).

Sustainable Agriculture Network (SAN), (2010). Sustainable agriculture standard (July 2010 version 2). San Jose, Costa Rica: Sustainable Agriculture Network.

Retrieved from: http://sanstandards.org/userfiles/SAN-S-11\%20SAN\%20Sustainable\%20Agriculture\%20Standard\%20July\%202010\%20v 2.pdf

Sustainable Agriculture Network (SAN), (2011). SAN climate module, criteria for mitigation and adaptation to climate change (February 2011). San Jose, Costa Rica: Sustainable Agriculture Network. Retrieved from: http://www.fao.org/fileadmin/user_upload/rome2007/docs/SAN\%20Climate\%2 0Module\%20February\%202011.pdf

Starbucks C.A.F.E Practices (no date). Starbucks C.A.F.E Practices (http://www.scsglobalservices.com/starbucks-cafe-practices).

Tesco. (2013). Tesco NURTURE (http://www.tesco.com/nurture/?page=nurturescheme).

Thomassen, M. A., Dalgaard, R., Hijungs, R., \& de Boer, I. (2008). Attributional and consequential LCA of milk production. International Journal of Life Cycle Assessment, 13, 339-349. doi: 10.1007/s11367-008-0007-y

Trexler, M. C. (2011). GHG measurement and management are vital, but always be looking to advance the end game of mitigating climate change. Greenhouse Gas Measurement and Management, 1, 77-79. doi: 10.1080/20430779.2011.579353 
Unilever. (2010a). Unilever sustainable living plan. Retrieved from:

http://www.sustainable-living.unilever.com/wpcontent/uploads/2010/10/UnileverSustainabilityPlan2.pdf

Unilever. (2010b). Unilever sustainable agriculture code (Version 1). Rotterdam, The Netherlands: Unilever. Retrieved from:

http://www.unilever.com/images/sd_Unilever_Sustainable_Agriculture_Code_2 010_tcm13-216557.pdf

Unilever. (2012). Unilever sustainable sourcing programme for agricultural raw materials, scheme rules. Retrieved from: http:// unileverrss.com/images/SchemeRulesBooklettcm13277688.pdf

United Nations Framework Convention on Climate Change (UNFCCC). (2009). Kyoto Protocol. Retrieved from: http://www.unfccc.int

UTZ Certified (2009). UTZ certified good inside code of conduct for cocoa for individual certification (Version 1.0-December 2009). Amsterdam: UTZ. Retrieved from: http://www.utzcertified-trainingcenter.com

Van der Werf, H. M. G. \& Petit, J. (2002). Evaluation of the environmental impact of agriculture at the farm level: a comparison and analysis of 12 indicator based methods. Agriculture, Ecosystems \& Environment, 93, 131-145. doi: 10.1016/S0167-8809(01)00354-1

Walter, S., Cole, D., Kathe, W., Lovett, P., \& Paz Soldàn, M. (2003). Impact of certification on the sustainable use of NWFP: lessons-learnt from three case studies, Revista De Desenvolvimento Economico, 8, 5-18. Retrieved from: http://revistas.unifacs.br/index.php/rde/article/viewFile/118/272

World Resources Institute (WRI) \& World Business Council for Sustainable Development (WBCSD). (2011). The greenhouse gas protocol: Product life cycle accounting and reporting standard. Retrieved from: http://www.ghgprotocol.org/files/ghgp/Product\%20Life\%20Cycle\%20Accounti ng\%20and\%20Reporting\%20Standard.pdf 


\begin{tabular}{|c|c|c|c|c|c|}
\hline Type & Scheme & Establishment & Products certifiable & $\begin{array}{l}\text { Scheme's declared description and } \\
\text { aim }\end{array}$ & $\begin{array}{l}\text { Document(s) reviewed to } \\
\text { assess scheme }\end{array}$ \\
\hline \multirow{5}{*}{ 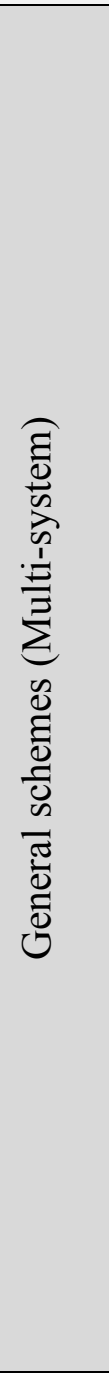 } & Fairtrade (FT) & $\begin{array}{l}\text { First label in } \\
\text { 1988. In } 1997 \\
\text { FLO was } \\
\text { established. }\end{array}$ & $\begin{array}{l}\text { Agriculture, composite } \\
\text { and manufactured goods } \\
\text { incl. bananas, cotton, } \\
\text { coffee, flowers, juice, } \\
\text { rice, spices, sport balls, } \\
\text { sugar, tea, wine. }\end{array}$ & $\begin{array}{l}\text { Fairtrade International (previously FLO - } \\
\text { Fairtrade Labelling Organisation) unites all } \\
\text { Fairtrade labelling initiatives. It aims to } \\
\text { provide fairer terms of trade for farmers in } \\
\text { the developing world through better prices, } \\
\text { working conditions and local sustainability. }\end{array}$ & $\begin{array}{l}\text { Fairtrade standard for small } \\
\text { producer organisations, version } \\
01.05 .2011 \text { v1.1 (2011). } \\
\\
\text { Explanatory document for the } \\
\text { Fairtrade standard for small } \\
\text { producer organisations (no date). }\end{array}$ \\
\hline & GlobalG.A.P. & $\begin{array}{l}1997 \text { (as } \\
\text { EurepGAP) }\end{array}$ & $\begin{array}{l}\text { Fruits, vegetables, } \\
\text { livestock, aquaculture, } \\
\text { production, plant } \\
\text { propagation materials } \\
\text { and compound feed } \\
\text { manufacturing. }\end{array}$ & $\begin{array}{l}\text { Formerly EurepG.A.P, GlobalG.A.P sets } \\
\text { voluntary standards for the certification of } \\
\text { agricultural products globally with the aim } \\
\text { to establish one standard for good } \\
\text { agricultural practices (GAPs) with multiple } \\
\text { product applications. It is a business-to-- } \\
\text { business standard focused on processes } \\
\text { along the value-chain, primarily on health } \\
\text { and safety risks. }\end{array}$ & $\begin{array}{l}\text { GlobalG.A.P. integrated farm } \\
\text { assurance, all farm base, control } \\
\text { points and compliance criteria, } \\
\text { (2012). } \\
\text { GlobalG.A.P. integrated farm } \\
\text { assurance, crops base, control } \\
\text { points and compliance criteria, } \\
\text { (2012). }\end{array}$ \\
\hline & $\begin{array}{l}\text { Linking } \\
\text { Environment and } \\
\text { Farming (LEAF) }\end{array}$ & 1991 & $\begin{array}{l}\text { All agriculturally } \\
\text { produced materials. }\end{array}$ & $\begin{array}{l}\text { LEAF promotes environmentally } \\
\text { responsible farming. It is built around } \\
\text { whole-farm principles of integrated farm } \\
\text { management (IFM) aiming to achieve a } \\
\text { balance between modern technology and } \\
\text { sound traditional methods to enrich the } \\
\text { environment and produce good food } \\
\text { products. }\end{array}$ & $\begin{array}{l}\text { LEAF Marque global standard, } \\
\text { Version } 10.0 \text { (2012). } \\
\text { LEAF Marque standard additional } \\
\text { guidance notes } 2012 \text { version } 1\end{array}$ \\
\hline & $\begin{array}{l}\text { Sustainable } \\
\text { Agriculture } \\
\text { Network (SAN), } \\
\text { Rainforest Alliance } \\
\text { (RA) }\end{array}$ & $\begin{array}{l}1987 \text { Rainforest } \\
\text { Alliance was } \\
\text { founded and the } \\
\text { SAN group } \\
\text { formally formed } \\
\text { in } 1997 .\end{array}$ & $\begin{array}{l}\text { Agricultural products } \\
\text { incl. cocoa, coffee, tea, } \\
\text { banana, flowers, } \\
\text { pineapple, citrus fruits, } \\
\text { avocado, grapes, } \\
\text { plantain, rubber and } \\
\text { vanilla. Forestry } \\
\text { products incl. timber \& } \\
\text { paper. }\end{array}$ & $\begin{array}{l}\text { Aims to conserve biodiversity and ensure } \\
\text { sustainable livelihoods by transforming } \\
\text { land-use practices, business practices and } \\
\text { consumer behaviour. }\end{array}$ & $\begin{array}{l}\text { Sustainable agriculture standard } \\
\text { (SAN), (2010). }\end{array}$ \\
\hline & SAN, Rainforest & 2011 & As above. & The new climate module aims to increase & SAN Climate Module: Criteria for \\
\hline
\end{tabular}




\begin{tabular}{|c|c|c|c|c|c|}
\hline & $\begin{array}{l}\text { Alliance Climate } \\
\text { Module (RA-CM) }\end{array}$ & & & $\begin{array}{l}\text { farmers' awareness of climate change } \\
\text { impacts and promote adoption of good } \\
\text { agricultural practices (GAPs) that reduce } \\
\text { GHGs, increase carbon sequestration and } \\
\text { enhance farms capacity to adapt. It is an } \\
\text { add-on to the SAN standard enabling } \\
\text { farmers to demonstrate use of climate- } \\
\text { friendly agricultural practices. }\end{array}$ & $\begin{array}{l}\text { the mitigation of and adaptation to } \\
\text { climate change (2011). }\end{array}$ \\
\hline & $\begin{array}{l}\text { Unilever } \\
\text { Sustainable } \\
\text { Agriculture Code } \\
\text { (UL SAC) }\end{array}$ & 2010 & $\begin{array}{l}\text { All agriculturally } \\
\text { produced materials. }\end{array}$ & $\begin{array}{l}\text { Unilever's SAC prescribes the practices that } \\
\text { all Unilever suppliers should strive to } \\
\text { achieve. The code is applicable to all } \\
\text { Unilever's sourced raw agricultural } \\
\text { materials globally. }\end{array}$ & $\begin{array}{l}\text { Unilever sustainable agriculture } \\
\text { code (Unilever } 2010 \text { b). }\end{array}$ \\
\hline 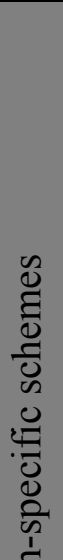 & $\begin{array}{l}\text { Better Sugar } \\
\text { Initiative } \\
\text { (Bonsucro) }\end{array}$ & 2010 & Sugarcane & $\begin{array}{l}\text { Bonsucro fosters the sustainability of the } \\
\text { sugarcane sector through a metric-based } \\
\text { certification scheme and by supporting } \\
\text { continuous improvement. The scheme aims } \\
\text { to provide a mechanism for achieving } \\
\text { sustainable production from sugarcane } \\
\text { products in respect of economic, social and } \\
\text { environmental dimensions. In } 2011 \\
\text { Bonsucro was recognised as meeting the } \\
\text { sustainability criteria under Directives } \\
\text { 2009/28/EC and } 2009 / 30 / \text { EC of the } \\
\text { European Commission for biofuel } \\
\text { certification as part of the Renewable } \\
\text { Energy Directive (RED). }\end{array}$ & $\begin{array}{l}\text { Bonsucro production standard } \\
\text { including Bonsucro EU } \\
\text { production standard (2011). }\end{array}$ \\
\hline$\overbrace{\infty}^{\frac{\pi}{0}}$ & $\begin{array}{l}\text { Roundtable on } \\
\text { Sustainable Palm } \\
\text { Oil (RSPO) }\end{array}$ & $\begin{array}{l}\text { Formed in } 2004 . \\
\text { In } 2005 \text { the } \\
\text { principles were } \\
\text { set and the criteria } \\
\text { and indicators } \\
\text { followed in } 2007 . \\
\text { First certification } \\
\text { granted in } 2008 .\end{array}$ & Palm oil & $\begin{array}{l}\text { The RSPO brings together stakeholders from } \\
\text { seven sectors of the palm oil industry: } \\
\text { producers, processors and traders, consumer } \\
\text { goods manufacturers, retailers, banks and } \\
\text { investors and environmental and } \\
\text { developmental NGOs, to develop global } \\
\text { standards for sustainable palm oil. Their aim } \\
\text { is to transform the market and make } \\
\text { sustainable palm oil the norm. RSPO was }\end{array}$ & $\begin{array}{l}\text { RSPO- principles and criteria for } \\
\text { sustainable palm oil production } \\
\text { (2007). } \\
\text { Colombia's national interpretation } \\
\text { of RSPO (2010). } \\
\text { RSPO-RED requirements for } \\
\text { compliance with the EU }\end{array}$ \\
\hline
\end{tabular}




\begin{tabular}{|c|c|c|c|c|}
\hline & & & $\begin{array}{l}\text { approved for biofuel production under RED } \\
\text { in } 2012 \text {. }\end{array}$ & $\begin{array}{l}\text { Renewable Energy Directive } \\
\text { requirements. Version 4-10 } \\
\text { February } 2012 .\end{array}$ \\
\hline $\begin{array}{l}\text { Roundtable of } \\
\text { Responsible Soy } \\
\text { (RTRS) }\end{array}$ & $\begin{array}{l}\text { Roundtable } \\
\text { formed in } 2006 . \\
\text { The standard was } \\
\text { published in } 2010 \\
\text { with first } \\
\text { certifications in } \\
2011 .\end{array}$ & Soy & $\begin{array}{l}\text { Aims to promote responsible soy production, } \\
\text { processing and trade worldwide. It is a } \\
\text { multi-stakeholder initiative including } \\
\text { industry, NGOs and producers. Countries } \\
\text { are encouraged to create national } \\
\text { interpretations of the core standard. In } 2011 \\
\text { RTRS developed a derivative of their } \\
\text { production standard that was recognised to } \\
\text { be compliant with the sustainability criteria } \\
\text { for biofuel certification under RED. }\end{array}$ & $\begin{array}{l}\text { RTRS standard for responsible } \\
\text { soy production, (2011). } \\
\text { RTRS EU RED compliance } \\
\text { requirements for producers, } \\
\text { Version 3.0_Eng, (2011). }\end{array}$ \\
\hline UTZ & 1997 & $\begin{array}{l}\text { Coffee, cocoa, tea, palm } \\
\text { oil, cotton. }\end{array}$ & $\begin{array}{l}\text { UTZ promotes sustainable farming through } \\
\text { assurance of GAPs and management, safe } \\
\text { and healthy working conditions, and } \\
\text { protection of the environment. UTZ seeks to } \\
\text { create transparency along the chain and } \\
\text { reward responsible producers. }\end{array}$ & $\begin{array}{l}\text { UTZ certified good inside code of } \\
\text { conduct for cocoa for individual } \\
\text { certification, version } 1.0 \text { (2009). }\end{array}$ \\
\hline
\end{tabular}




\begin{tabular}{|c|c|c|c|}
\hline ID & GHG Driver (D) & $\begin{array}{c}\text { Descriptor (influences on GHG } \\
\text { emissions) }\end{array}$ & $\begin{array}{l}\text { Schemes assessed } \\
\text { for the GHG } \\
\text { driver }\end{array}$ \\
\hline \multicolumn{4}{|c|}{ Upstream GHG drivers } \\
\hline $\mathbf{a}$ & $\begin{array}{l}\text { Fertiliser } \\
\text { production }\end{array}$ & $\begin{array}{l}\text { Energy requirement in the } \\
\text { manufacture of synthetic fertilisers } \\
\text { for use on farm; manufacture } \\
\text { process e.g. ammonia; chemicals } \\
\text { used. }\end{array}$ & All \\
\hline b & $\begin{array}{l}\text { Crop protection } \\
\text { chemical (CPC) } \\
\text { production }\end{array}$ & $\begin{array}{l}\text { Energy requirement in the } \\
\text { manufacture of synthetic CPCs for } \\
\text { use on farm, including chemical } \\
\text { feedstocks used. }\end{array}$ & All \\
\hline $\mathbf{c}$ & $\begin{array}{l}\text { Transport of inputs } \\
\text { to farm }\end{array}$ & $\begin{array}{l}\text { Locality of input sources; energy } \\
\text { requirement for travel; fuel } \\
\text { combustion; distance travelled; } \\
\text { mode of transportation. }\end{array}$ & All \\
\hline \multicolumn{4}{|c|}{ On-farm GHG emission drivers } \\
\hline d & Fertilisers & $\begin{array}{l}\text { Fertiliser application; amount; } \\
\text { types; timing; good practice; } \\
\text { precision application; fuel } \\
\text { combustion by application } \\
\text { machinery. }\end{array}$ & All \\
\hline $\mathbf{e}$ & $\begin{array}{l}\text { Crop protection } \\
\text { chemicals (CPCs) } \\
\text { (pesticides, } \\
\text { herbicides, } \\
\text { insecticides etc.) }\end{array}$ & $\begin{array}{l}\text { Pesticide application; amount; } \\
\text { types; good practice; precision } \\
\text { application; fuel combustion by } \\
\text { application machinery. }\end{array}$ & All \\
\hline $\mathbf{f}$ & Soil & $\begin{array}{l}\text { Practices to maintain and enhance } \\
\text { soil structure/quality; measures of } \\
\text { soil quality/fertility and soil types. }\end{array}$ & All \\
\hline g & $\begin{array}{l}\text { Cropping } \\
\text { operations }\end{array}$ & $\begin{array}{l}\text { Good practice for machinery use } \\
\text { for crop cultivation including but } \\
\text { not limited to sowing, seed input, } \\
\text { fertilisation, harvest, mechanical } \\
\text { weeding; maintenance of } \\
\text { machinery; use records; energy } \\
\text { inputs and fuel combustion; } \\
\text { machine efficiency. }\end{array}$ & All \\
\hline $\mathbf{h}$ & $\begin{array}{l}\text { Tillage machinery } \\
\text { use }\end{array}$ & $\begin{array}{l}\text { Good practice for machinery use } \\
\text { for ploughing operations; } \\
\text { maintenance of machinery; use } \\
\text { records; energy inputs and fuel } \\
\text { combustion. }\end{array}$ & All \\
\hline
\end{tabular}




\begin{tabular}{|c|c|c|c|}
\hline $\mathbf{i}$ & Irrigation & $\begin{array}{l}\text { Irrigation practices; water use } \\
\text { efficiencies; records; energy use } \\
\text { and fuel combustion. }\end{array}$ & All except RSPO \\
\hline $\mathbf{j}$ & Transport & $\begin{array}{l}\text { Transport related energy of } \\
\text { materials and inputs on farm; fuel } \\
\text { use for transportation. }\end{array}$ & All \\
\hline $\mathbf{k}$ & $\begin{array}{l}\text { Non-specific energy } \\
\text { use }\end{array}$ & $\begin{array}{l}\text { General energy management; } \\
\text { energy efficiencies; energy use } \\
\text { records and fuel combustion. }\end{array}$ & All \\
\hline 1 & Land use change & $\begin{array}{l}\text { Transformation of land; expansion } \\
\text { onto new land; deforestation. }\end{array}$ & All \\
\hline $\mathbf{m}$ & Land Clearing & $\begin{array}{l}\text { Land clearing practices; fire } \\
\text { management; gas capture. }\end{array}$ & $\begin{array}{l}\text { RSPO, RTRS, } \\
\text { BonSucro, UL } \\
\text { SAC }\end{array}$ \\
\hline $\mathbf{n}$ & Organic soils & $\begin{array}{l}\text { Cultivation and preservation of } \\
\text { organic soils, especially peat soils. }\end{array}$ & All \\
\hline $\mathbf{0}$ & Agroforestry & $\begin{array}{l}\text { Conversion or enhancement of land } \\
\text { into forest land; biodiversity } \\
\text { enhancement; planting of trees; } \\
\text { buffer strips; hedgerow } \\
\text { maintenance; shade trees (where } \\
\text { applicable). }\end{array}$ & All \\
\hline $\mathbf{p}$ & Waste crop residue & $\begin{array}{l}\text { Residue incorporation; } \\
\text { management practices; responsible } \\
\text { disposal; quantity/use records. }\end{array}$ & All \\
\hline $\mathbf{q}$ & Livestock & $\begin{array}{l}\text { Livestock management practices; } \\
\text { livestock health; feed records. }\end{array}$ & $\begin{array}{l}\text { RA, RA-CM, UL } \\
\text { SAC, LEAF. }\end{array}$ \\
\hline $\mathbf{r}$ & Manure & $\begin{array}{l}\text { Manure/slurry incorporation; } \\
\text { management practices; responsible } \\
\text { disposal; quantity/use records. }\end{array}$ & $\begin{array}{l}\text { RA, RA-CM, UL } \\
\text { SAC, LEAF. }\end{array}$ \\
\hline $\mathbf{S}$ & $\begin{array}{l}\text { On-site energy } \\
\text { production }\end{array}$ & $\begin{array}{l}\text { By-product material use for energy; } \\
\text { combined heat and power on farm, } \\
\text { etc. }\end{array}$ & All \\
\hline $\mathbf{t}$ & $\begin{array}{l}\text { Rice paddy } \\
\text { cultivation }\end{array}$ & $\begin{array}{l}\text { Rice paddy management practices; } \\
\text { flooding; } \\
\text { management/capture etc. }\end{array}$ & $\begin{array}{l}\text { UL SAC, LEAF, } \\
\text { GlobalG.A.P. }\end{array}$ \\
\hline \multicolumn{4}{|c|}{ GHG Specific criteria } \\
\hline $\mathbf{u}$ & GHG commitments & $\begin{array}{l}\text { Requirements specific to GHG } \\
\text { emissions: carbon management; } \\
\text { GHG emissions; climate change } \\
\text { mitigation; targets; minimum }\end{array}$ & All \\
\hline
\end{tabular}




\begin{tabular}{|l|l|l|c|}
\hline & & $\begin{array}{l}\text { requirements; calculations; default } \\
\text { values; calculator use. }\end{array}$ & \\
\hline $\mathbf{v}$ & Carbon neutrality & $\begin{array}{l}\text { Promotion of carbon neutrality; net } \\
\text { GHG balance. }\end{array}$ & All \\
\hline $\mathbf{w}$ & Carbon offsets & $\begin{array}{l}\text { Requirements/calculations } \\
\text { regarding carbon offsetting. }\end{array}$ & All \\
\hline
\end{tabular}




\begin{tabular}{|c|c|c|c|}
\hline ID & $\begin{array}{c}\text { Intervention } \\
\text { Classification (I) }\end{array}$ & Definition & $\begin{array}{c}\text { Examples of } \\
\text { nomenclature }\end{array}$ \\
\hline I1 & Manage & $\begin{array}{l}\text { The structures, policies and } \\
\text { practices in place to manage GHG } \\
\text { drivers and address GHG specific } \\
\text { criteria. Requirements or } \\
\text { instructions for result-oriented } \\
\text { action; e.g. the implementation of } \\
\text { good practices to address or control } \\
\text { the GHG drivers, including training } \\
\text { related to good management. }\end{array}$ & $\begin{array}{l}\text { Management } \\
\text { plans; policy; } \\
\text { controls; design; } \\
\text { training; } \\
\text { knowledge } \\
\text { generation; } \\
\text { implementation of } \\
\text { good practices; } \\
\text { maintenance of } \\
\text { good conditions; } \\
\text { action. }\end{array}$ \\
\hline I2 & Measure & $\begin{array}{l}\text { Requires measured and recorded } \\
\text { performance related data e.g. } \\
\text { through record keeping, } \\
\text { assessments and analysis. The } \\
\text { measurement and recording of } \\
\text { numerical activity data (such as } \\
\text { litres of fuel used) or creation of an } \\
\text { activity inventory that can be } \\
\text { converted into GHG performance } \\
\text { data using emission factors. } \\
\text { Demonstrations of good } \\
\text { management leading to GHG } \\
\text { emission performance information. }\end{array}$ & $\begin{array}{l}\text { Monitoring and } \\
\text { recording; } \\
\text { documenting of } \\
\text { quantitative data; } \\
\text { energy use/fuel use } \\
\text { records; evaluate } \\
\text { impacts; meter } \\
\text { reading; activity } \\
\text { mapping; } \\
\text { efficiency } \\
\text { calculations; } \\
\text { baseline } \\
\text { calculation; default } \\
\text { values; primary } \\
\text { data; inventory. }\end{array}$ \\
\hline I3 & $\begin{array}{l}\text { Performance } \\
\text { standard }\end{array}$ & $\begin{array}{l}\text { Requires an explicit reduction } \\
\text { target or improvement of the GHG } \\
\text { driver that will/is likely to result in } \\
\text { associated GHG reductions. } \\
\text { Explicit target to enhance } \\
\text { sequestration of GHGs where } \\
\text { applicable. Evidence of } \\
\text { reduction/improvement or time- } \\
\text { bound commitment; e.g. } \\
\text { demonstrate an impact reduction } \\
\text { through metrics, calculations with } \\
\text { impact/use required to remain } \\
\text { below a specified range or } \\
\text { threshold. }\end{array}$ & $\begin{array}{l}\text { Defined targets; } \\
\text { evidence of } \\
\text { reductions over } \\
\text { time; evidence of } \\
\text { phase } \\
\text { out/elimination; } \\
\text { time bound plan; } \\
\text { demonstrate } \\
\text { improvements; } \\
\text { show increased } \\
\text { efficiency; } \\
\text { improved metrics; } \\
\text { commit to } \\
\text { mitigation; } \\
\text { threshold. }\end{array}$ \\
\hline
\end{tabular}




\begin{tabular}{|c|c|c|}
\hline $\begin{array}{c}\text { Stringency } \\
\text { classification }(\mathbf{S})\end{array}$ & Definition & Nomenclature \\
\hline Hard & $\begin{array}{l}\text { Criterion must be met in order } \\
\text { for the certification to be } \\
\text { awarded. Immediate } \\
\text { requirement without exception. }\end{array}$ & $\begin{array}{l}\text { - Mandatory requirement } \\
\text { - } \text { Propitiatory requirement } \\
\text { - Critical Failure point } \\
\text { - Critical criterion }\end{array}$ \\
\hline Medium & $\begin{array}{l}\text { Criterion must be met under } \\
\text { particular conditions: specified } \\
\text { percentage compliance of a } \\
\text { chapter or section of the } \\
\text { scheme; implemented in a } \\
\text { specified time frame beyond } \\
\text { the year of the audit. }\end{array}$ & $\begin{array}{l}\text { - } \begin{array}{l}\text { General criteria } \\
\text { (percentage compliance) }\end{array} \\
\text { - } \text { Time bound requirement } \\
\text { - Development } \\
\text { requirement }\end{array}$ \\
\hline Soft & $\begin{array}{l}\text { Criterion is optional or } \\
\text { voluntary or is recommended } \\
\text { but with no evidence required } \\
\text { for action nor time } \\
\text { implementation deadline. }\end{array}$ & $\begin{array}{ll}\text { - } & \text { Recommended } \\
\text { requirement }\end{array}$ \\
\hline
\end{tabular}




\begin{tabular}{|c|c|c|}
\hline Score & Descriptor & $\begin{array}{l}\quad \text { Calculation } \\
(\mathrm{D}=\mathrm{GHG} \text { drivers; } \mathrm{I}= \\
\text { Intervention scores (I1, I2, I3); S } \\
=\text { Stringency scores }(\mathrm{S} 1, \mathrm{~S} 2, \mathrm{~S} 3)\end{array}$ \\
\hline Comprehensiveness & $\begin{array}{l}\text { The proportion of GHG drivers } \\
\text { addressed by the scheme. }\end{array}$ & (D score / Possible D score)*100 \\
\hline \multirow[t]{4}{*}{ Intervention } & \multirow{4}{*}{$\begin{array}{l}\text { The types of intervention for } \\
\text { which GHGs are addressed } \\
\text { within a scheme. A higher score } \\
\text { indicates greater inclusion of } \\
\text { more intervention classifications } \\
\text { (I1, I2, I3). This score can also } \\
\text { be divided to look at the } \\
\text { intervention score at each type; } \\
\text { I1 = management intervention; } \\
\text { I2 measurement intervention; I3 } \\
\text { performance standard } \\
\text { intervention. }\end{array}$} & $\begin{array}{c}\text { Overall Intervention score }(\mathrm{I})= \\
\sum \mathrm{D} \text { a-w }(\mathrm{I} 1, \mathrm{I} 2, \mathrm{I} 3) / \text { Possible D } \\
\text { score*3 }\end{array}$ \\
\hline & & $\begin{array}{c}\mathrm{I} 1=\left(\left(\sum \text { I1 score }\right) /(\text { Potential I1 }\right. \\
\text { score })) * 100\end{array}$ \\
\hline & & $\begin{array}{c}\mathrm{I} 2=\left(\left(\sum \mathrm{I} 2 \text { score }\right) /(\text { Potential I } 2\right. \\
\text { score })) * 100\end{array}$ \\
\hline & & $\begin{array}{c}\mathrm{I} 3=\left(\left(\sum \mathrm{I} 3 \text { score }\right) /(\text { Potential I3 }\right. \\
\text { score })) * 100\end{array}$ \\
\hline Stringency & $\begin{array}{l}\text { The relative level of strictness } \\
\text { for compliance to receive } \\
\text { certification; a higher score } \\
\text { indicates that a scheme is stricter } \\
\text { in requiring compliance } \\
\text { concerning GHG drivers. }\end{array}$ & $\begin{array}{c}\left(\left(\sum \mathrm{S} 1+\mathrm{S} 2+\mathrm{S} 3\right) / \text { possible } \mathrm{S}\right. \\
\text { score }) * 100\end{array}$ \\
\hline
\end{tabular}




\begin{tabular}{|l|c|c|c|c|}
\hline \multicolumn{1}{|c|}{ Scheme } & $\begin{array}{c}\text { Potential } \\
\text { score* }\end{array}$ & $\begin{array}{c}\text { Total } \\
\text { comprehensive- } \\
\text { ness score (\%) }\end{array}$ & $\begin{array}{c}\text { Total ambition } \\
\text { score (\%) }\end{array}$ & $\begin{array}{c}\text { Total } \\
\text { stringency } \\
\text { score (\%) }\end{array}$ \\
\hline Fairtrade & 240 & 40 & 18 & 13 \\
\hline GlobalG.A.P & 252 & 38 & 21 & 13 \\
\hline LEAF & 276 & 65 & 45 & 38 \\
\hline RA & 264 & 68 & 39 & 28 \\
\hline RA+RA-CM & 264 & 86 & 50 & 35 \\
\hline UL SAC & 276 & 78 & 48 & 39 \\
\hline Bonsucro & 240 & 75 & 58 & 42 \\
\hline RSPO & 228 & 63 & 35 & 35 \\
\hline RSPO+RSPO- & 228 & 63 & 37 & 38 \\
EU & 240 & 70 & 38 & 46 \\
\hline RTRS & 240 & 75 & 47 & 23 \\
\hline RTRS+RTRS- & 240 & 50 & 28 & 37 \\
EU & & &
\end{tabular}


Figure 1

Font: calibri

Origin: Microsoft exce1/PC

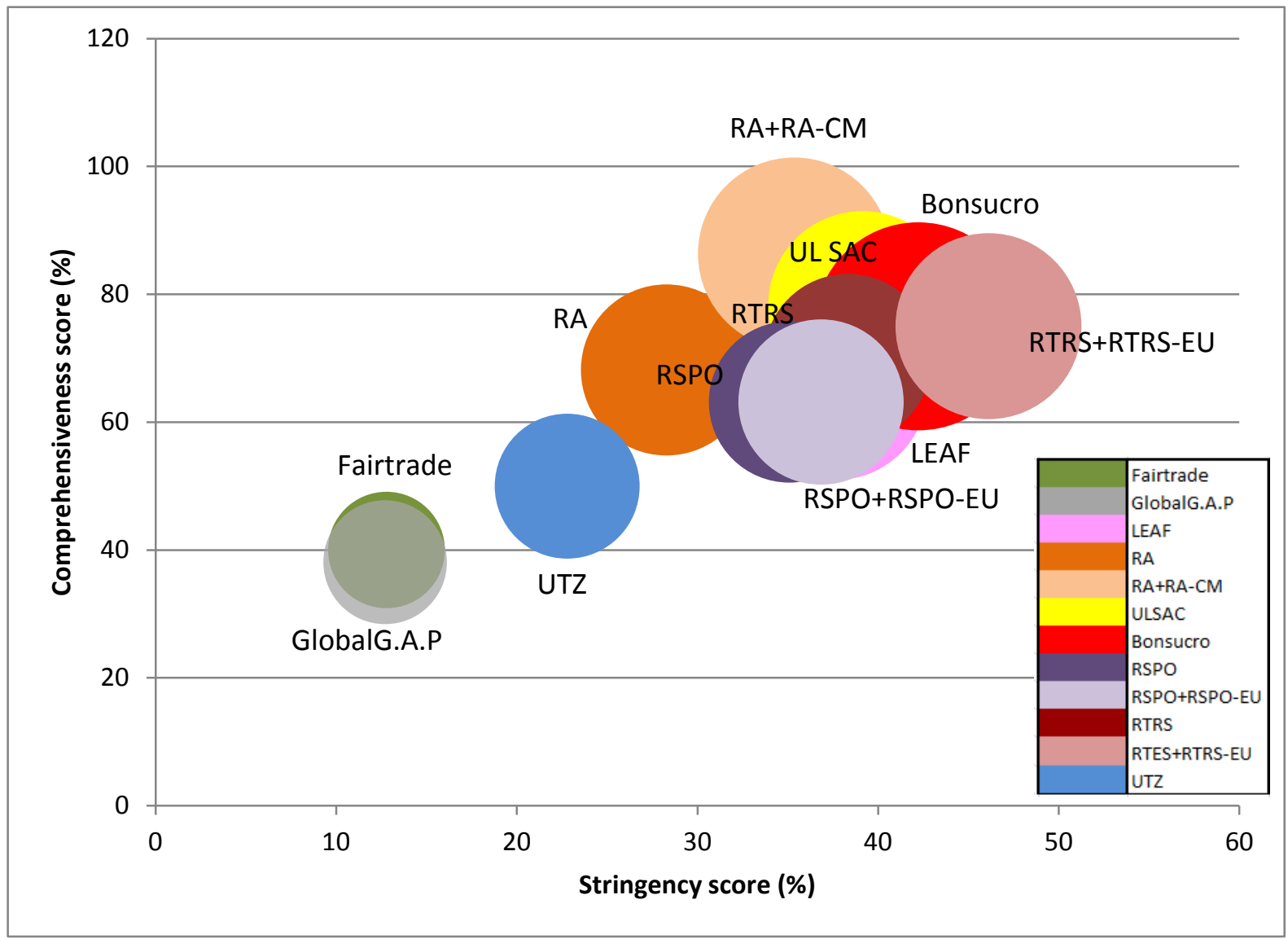


Figure 2

Font: calibri

Origin: excel/pc and edited in paint

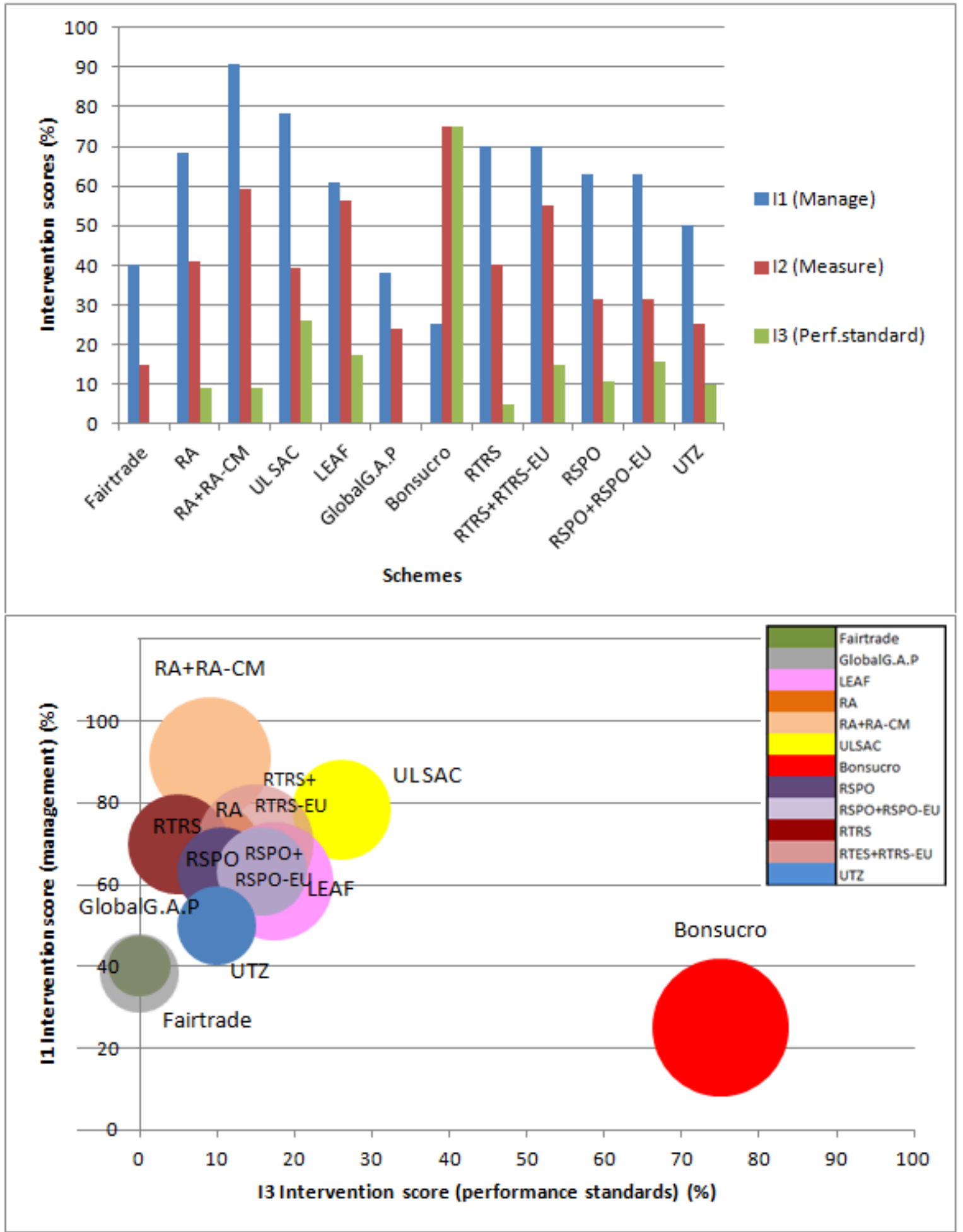


Figure 3

Font: calibri

Origin: Excel/pc and edited in paint

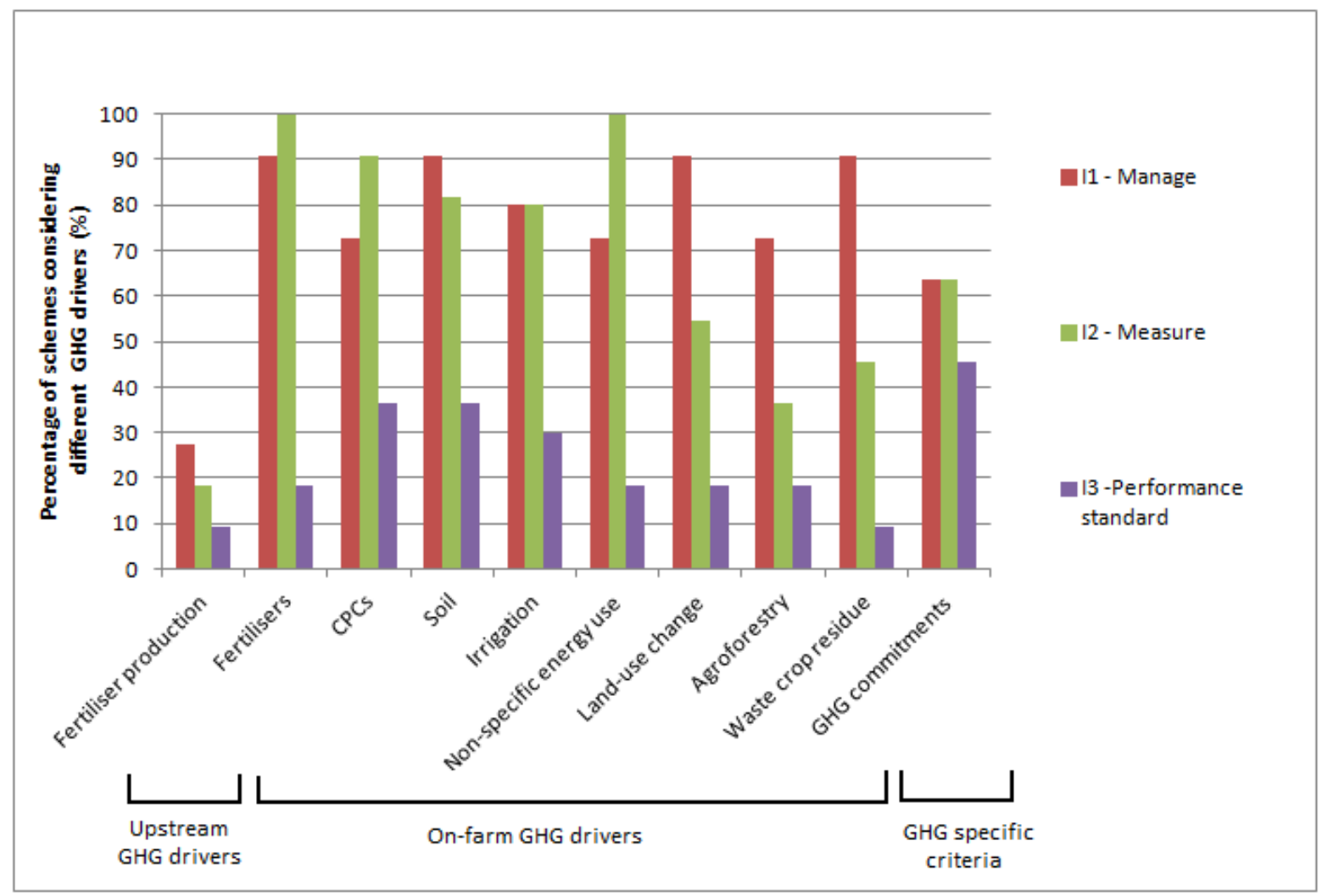

